\title{
Success and Failure: Countdown and Zero
}

\author{
Andisa Oktaviana \\ Program Studi Kewirausahaan \\ Universitas Bina Nusantara \\ andisa.oktaviana@binus.ac.id
}

Kesuksesan dan kegagalan bagi seorang entrepreneur adalah hal yang wajar atau sering kali dialami oleh pengusaha dalam menjalankan sebuah bisnis. Kesuksesan dan kegagalan tersebut dimulai dengan adanya pesaing atau competitor yang lebih berkompeten dalam hal mengembangkan atau menciptakan sebuah ide bisnis yang kreatif dan inovatif (Beaver, 2003). Selain itu, membangun dan menjalankan sebuah bisnis adalah suatu hak dan kewajiban yang harus dimiliki bagi seorang entrepreneur atau pengusaha.

Pengusaha pada awalnya tidak memiliki ide sama sekali atau layaknya seperti angka nol, sebelum membangun dan menjalankan sebuah bisnis. Angka nol diartikan sebagai permulaan dari semua kegiatan yang akan dilakukan. Angka nol dalam hal bisnis, dimaksudkan sebagai awal untuk membangun sebuah bisnis dengan memperhatikan beberapa aspek sebagai berikut.

1. Menentukan arah dan tujuan bisnis

Hal tersebut mencakup target pasar. Apa yang ingin dijual dan bagaimana cara untuk memperoleh profit yang besar.

2. Unik dan berbeda dari pesaing atau kompetitor lain

Hal ini dimaksudkan agar pengusaha membuat produk yang unik atau spesial, sehingga konsumen akan tertarik dengan produk yang ditawarkan dan membeli produk tersebut.

3. Riset Pasar

Melakukan riset pasar, bertujuan agar kita dapat mengukur sejauh mana daya beli masyarakat terhadap produk yang nantinya akan kita perjual-belikan kepada konsumen.

4. Menentukan strategi marketing

Strategi marketing sangat diperlukan bagi entrepreneur dan pengusaha. Strategi marketing yang baik, akan menarik minat konsumen atau sesuai dengan target yang telah ditentukan sebelumnya.

5. Mengetahui dan menilai pesaing

Hal tersebut dimaksudkan agar kita dapat melihat kekurangan bisnis dari pesaing atau kompetitor lain, sehingga kita dapat mengembangkan keunggulan yang dimiliki oleh bisnis dari pesaing atau competitor. Hal ini bertujuan agar 
bisnis yang kita bangun dan jalankan dapat berjalan dengan baik, lancar dan mendapatkan profit yang besar.

6. Mengatur keuangan dalam bisnis

Dengan mengatur dan mengelola keuangan dengan sebaik-baiknya, maka bisnis yang akan dijalankan akan terhindar dari adanya kebangkrutan dan kegagalan.

COVID-19 pertama kali di ketahui di Kota Wuhan, China pada awal Desember tahun 2019 dan kini mulai menyebar hingga ke semua negara. COVID-19 disebabkan oleh adanya virus yang bernama virus novel severe acute respiratory syndrome coronavirus 2 (SARS-CoV-2) (Safitri et al., 2020). Pandemi COVID-19 membuat semua sektor menjadi hancur atau berantakan. Hal ini berdampak pada sektor ekonomi sehingga nilai kurs rupiah terhadap dolar Amerika Serikat mengalami fluktuasi yang cukup besar. Selain itu, dengan adanya kinerja ekonomi yang melemah, menimbulkan banyaknya pengangguran dan pasar tenaga kerja mengalami pasca krisis. Dampak pada sektor pendidikan dan pekerjaan menimbulkan banyak pelajar dan pegawai yang beraktifitas di rumah Learn from Home dan Work from Home (LFH dan WFH). Dampak COVID-19 ini tidak hanya berimbas pada sektor ekonomi, pendidikan dan pekerjaan saja tetapi berimbas pada sektor-sektor lainnya. Pemerintah mulai mencari solusi untuk mengatasi permasalahan tersebut yaitu dengan cara:

1. Wajib menggunakan masker dan melakukan $5 \mathrm{M}$ yaitu mencuci tangan, memakai masker, menjaga jarak, membatasi mobilitas dan interaksi, menjauhi kerumunan.

2. Mewajibkan masyarakat untuk melakukan dan mendapatkan vaksin.

3. Membuat dan mewajibkan untuk menggunakan aplikasi peduli lindungi.

4. Memberlakukan ganjil-genap bagi kendaraan roda dua maupun roda empat.

5. Mewajibkan bagi masyarakat yang ingin bepergian keluar kota atau luar negeri untuk melakukan tes PCR atau Antigen.

6. Mewajibkan bagi masyarakat yang sebelumnya melakukan perjalanan ke luar negeri atau luar kota untuk melakukan isolasi mandiri sesuai dengan ketentuan yang berlaku.

Adanya ketentuan-ketentuan tersebut, Pemerintah dan masyarakat mengharapkan agar pandemi COVID-19 bisa segera selesai dan bisa beraktifitas kembali seperti sedia kala.

\section{References}

Barringer, B. R. (2015). Preparing Effective Business Plans: An Entrepreneurial Approach (2nd ed.). Pearson Education Limited.

Beaver, G. (2003). Small business: Success and Failure. In Strategic Change (Vol. 12, 
Issue 3, pp. 115-122).

Lussier, R. (1996). A Business Success versus Failure Prediction Model for Service Industries. In Journal of Business and Entrepreneurship (Vol. 8, Issue 2, p. 23).

Lussier, R. N. (1996). A Startup Business Success versus Failure Prediction Model for The Retail Industry. In The Mid - Atlantic Journal of Business (Vol. 32, Issue 2, p. 79).

Safitri, Y., Nugroho, L., Permana, S. D. H., Zonyfar, C., Purnia, D. S., Napitulu, D., Septiani, R., Sari, D. P., Utama, A. A. G. S., Kennedy, P. S. J., Kuncara, T., Fikri, Z., Siregar, E., Maulana, A. E., Lika, K., Purnomo, A., \& Tallo, A. J. (2020). Gotong Royong Menghadapi COVID-19: Ide dan Solusi. CV. Penerbit Qiara Media. https://books.google.co.id/books?id=AT8DEAAAQBAJ.

\section{Biografi}

\section{Andisa Oktaviana}

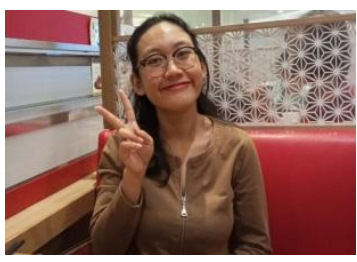

Penulis kelahiran Bekasi ini adalah seorang mahasiswa program studi kewirausahaan di Universitas Bina Nusantara, kampus Malang sejak tahun 2020. Andisa penggemar ELF, drama Korea dan warna hitam putih ini memiliki prinsip hidup bahwa "Hidup hanya sekali, maka pergunakanlah hidupmu dengan sebaikbaiknya. Selalu mendekat kepada Tuhan dan bersikap baik kepada sesama yang ada di sekitar kita tanpa membedakan satu dan yang lainnya" .

Email: andisa.oktaviana@binus.ac.id

Instagram: @disaoktaviana

Linkedin: https://www.linkedin.com/in/andisa-oktaviana-90a692217/ 